\title{
Discovery of a new genus of tanaidacean (Crustacea: Tanaidacea: Mirandotanaidae) found associated with a deep-sea terebellid polychaete
}

\author{
Eduardo Suárez-Morales ${ }^{1,4}$, Mario Londoño-Mesa², Richard W. Heard ${ }^{3}$ \\ ${ }^{1}$ El Colegio de la Frontera Sur (ECOSUR). Unidad Chetumal, Av. Centenario Km. 5.5. 77095. Chetumal, Quintana \\ Roo, Mexico \\ ${ }^{2}$ Grupo de Investigación en Sistemas Marinos y Costeros. Universidad de Antioquía. Medellín, Colombia \\ ${ }^{3}$ Department of Coastal Sciences. University of Southern Mississippi. Gulf Coast Research Laboratory Campus, \\ Ocean Springs, MS, USA \\ ${ }^{4}$ E-mail:esuarez@ecosur.mx
}

Key words: benthic biology, benthic crustaceans, symbiosis, tanaidaceans, terebellids

\begin{abstract}
Only one species of Tanaidacea, Expina typica, has been hitherto reported as an endosymbiont; it was recovered from the body cavity of deep-sea holothurians. During a survey of the deepsea benthic community in the Florida Straits off the Bahamas, Terebellatanais floridanus, a new genus and species of a tanaidomorphan tanaidacean was recovered at a depth of $545 \mathrm{~m}$ from the oral cavity of the terebellid polychaete Biremis blandi. Terebellatanais gen. nov. is tentatively assigned to the family Mirandotanaidae, as it appears to have affinities with Mirandotanais and Pooreotanais but also with Expina. It is distinguished from these genera by a unique combination of characters, including four antennular and antennal articles, a naked endite of the maxillipedal basis, hook-like chelipeds, the armature of the pereopods, and characters of the mouthparts. Most of the specimens of $T$. floridanus examined are mancas, but some were distinctly larger and with a different development of the last pereopod, thus suggesting that at least two manca stages are represented. The occurrence of the new genus and species within the oral cavity of B. blandi, its peculiar morphology, and the absence of fully grown adults, suggest that $T$. floridanus may be a symbiont of Biremis blandi at least during part of its development. Whether this relationship is commensal or parasitic remains to be determined.
\end{abstract}

\section{Contents}

Introduction

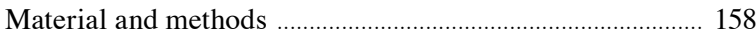

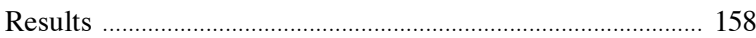

Systematic part ………………............................................ 158

Discussion ............................................................................. 159

Acknowledgements ................................................................ 160

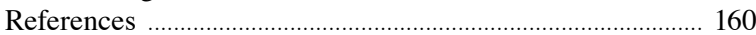

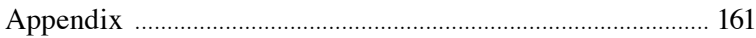

\section{Introduction}

Tanaidaceans are a diverse and widespread group of peracarid crustaceans containing about 1200 nominal species (Anderson, 2010). They have a worldwide distribution in marine and occasionally in brackish waters from the intertidal zone to depths exceeding $8000 \mathrm{~m}$. Only general aspects of their biology are known. They are sexually dimorphic and have a wide range of morphological variation during their ontogenetic development (Larsen and Wilson, 1998; Larsen, 2005). These crustaceans have successfully colonized marine benthic habitats and are relatively more abundant and diverse in the deep sea benthos (Lang, 1968; Larsen, 1999, 2005).

Though members of the crustacean order Tanaidacea exhibit a wide variety of forms in relation to their use of different habitats and the ways they interact with other fauna, most are free-living (Larsen, 2005). Some species, however, have been reported to be symbiotically associated with other invertebrates. These associations include molluscs, corals, sponges, and bryozoans, and in some instances vertebrates, including sea turtles and manatees (Bamber and Bird, 1997; Larsen, 2005; Morales-Vela et al., 2008). They are also known to inhabit tubes of other invertebrates (Thistle et al., 1985). Notwithstanding, the scarce evidence of true parasitism among tanaidaceans is not conclusive, but it has been suggested that one tanaidomorphan species, Expina typica Lang, 1968, may represent this type of relationship. This species for part of its life cycle has been reported as an endosymbiont of deep-sea holothurians (Thurston et al., 1987; Kudinova-Pasternak, 1987). 
During the examination of four specimens of the terebellid polychaete Biremis blandi Polloni, Rowe and Teal, 1973 from different areas of the Northwestern Atlantic (Londoño-Mesa, 2009), several tanaidaceans were found within the oral cavity of one of these specimens. The polychaete was collected from deep-sea benthic habitats $(545 \mathrm{~m})$ off the Florida Straits. This is a deep-living species originally described from the adjacent area off Nassau, Bahamas (Polloni et al., 1973; Londoño-Mesa, 2009). Subsequent examination of the tanaidaceans indicated that they represent an undescribed genus and species within the suborder Tanaidomorpha. The description of this new tanaidacean and a discussion of its possible association with the terebellid $B$. blandi are presented and discussed in herein.

\section{Material and methods}

Specimens of the terebellid polychaete Biremis blan$d i$ were collected by the R/V Pillsbury by personnel from the University of Florida. Samples were taken with a dredge at a depth of $545 \mathrm{~m}$ in June 1963 off Cay Sal Bank, in the Florida Straits $\left(24^{\circ} 15^{\prime} \mathrm{N}\right.$, $\left.80^{\circ} 05^{\prime} \mathrm{W}\right)$. Specimens were observed under the stereo-microscope to detect epibionts. In one polychaete several tanaidaceans $(+10)$ were detected and removed from the inner walls of the oral area (Fig. 1); other specimens were left within the oral cavity. The tanaidaceans were transferred to $70 \%$ ethanol for preservation and long-term storage. Drawings were prepared using a camera lucida. One specimen was used for SEM analysis; it was first dehydrated by transferring it to successively higher ethanol concentrations (40-100\%), then it was dried to critical point drier (CPD), thus leaving the specimen ready to receive the gold coat. The observations were performed using a JEOL LV5900 microscope at the facilities of the Universidad de Aguascalientes, Mexico. The holotype is deposited in the collection of Invertebrates of the National Museum of Natural History, Smithsonian Institution, Washington, D.C., United States (USNM); paratypes are deposited in the collection of Zooplankton of ECOSUR (ECO-CHZ) in Chetumal, the University of Miami, Miami, Florida (UMM), and in the museum of the Gulf Coast Research Laboratory (GCRL), University of Mississippi, in Ocean Springs. Unless indicated otherwise, the morphological terminology proposed by Larsen $(2003,2005)$ is used.

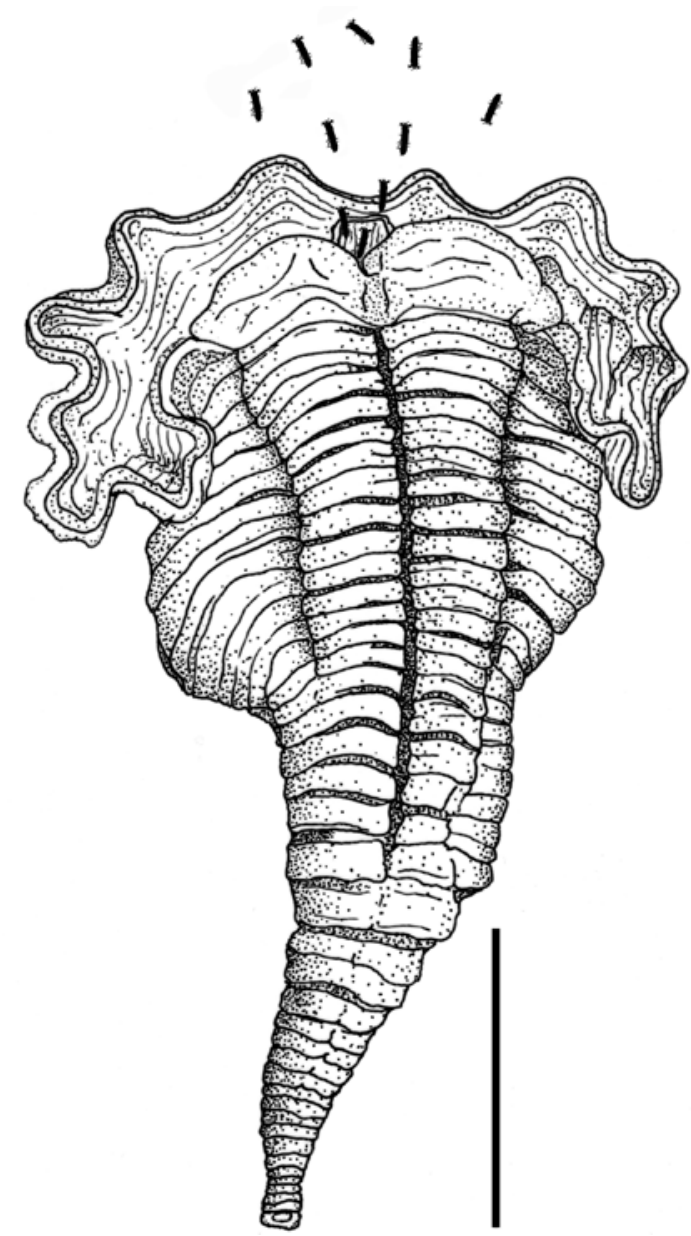

Fig. 1. Biremis blandi, the deep-living host polychaete of Terebellatanais floridanus gen. nov., sp. nov. specimen from Key Sal Bank, Straits of Florida (UMML22.1013), showing the relative size of the tanaidaceans. Scale bar $=50 \mathrm{~mm}$.

\section{Results}

\section{Systematic part}

Suborder Tanaidomorpha Sieg, 1980

Superfamily Paratanaoidea Lang, 1949

Family Mirandotanaidae Błażewicz-Paszkowycz and Bamber, 2009

Terebellatanais gen. nov

Terebellatanais floridanus sp. nov.

The results consist of the diagnosis and descriptions of the new genus and species; these can be found in the Appendix. 


\section{Discussion}

Terebellatanais floridanus sp. nov. is the first species of tanaidacean found in a possible symbiotic relationship with a polychaete. The fact that all the specimens recovered were clinging to the inner walls of the oral cavity of its polychaete "host" suggests an endosymbiotic, possibly commensal, relationship. This possibility seems to be further supported by the morphology of the hook-like chelae and the reduced mouth parts. Quite surprisingly, most of the specimens of T. floridanus examined are mancas. This condition would preclude the possibility of neoteny, at least at this stage of development. Some of these specimens still appeared to contain a yellowish yolk material or lymphoid liquid; it can be speculated also that this liquid material could have been obtained by the tanaidacean directly from the polychaete or its secretions.

The possible endobiotic association of $T$. floridanus with a deep-water polychaete host might be similar to that postulated for Expina typica, the only tanaidacean that has been previously reported as endosymbiont. Adults and neuters (i.e. no active reproductive adults) of this species have been observed in the body cavity of deep-water holothurians (Kudinova-Pasternak 1987, Thurston et al., 1987). Larsen (2005) suggested that $E$. typica is not an obligate symbiont as it has been found within tubes in the sediment; however, if it is determined that part of its development is dependent on its association with holothurians; this would not be the case. The genus Expina, and two other possible symbionts with enlarged pleon, Mirandotanais Kussakin and Tzareva, 1974 and Cetiopyge Larsen and Heard, 2002 exhibit a different reproductive strategy than that performed by other tanaidaceans. The ovigerous freeliving females, which apparently lack oostegites, enclose themselves into a "cocoon-like" incubatory case, where they deposit their eggs; the female remains within this case until the eggs develop into fully formed mancas (Larsen 2005, G. Bird and R. Heard, pers. obs.). What occurs after the mancas exit the incubatory case is only conjecture. They may remain freeliving in the sediment until they reach maturity or, in the case of E. typica, they may enter the body cavity of the holothurian to feed and develop into adult males and pre-incubatory females, which eventually exit the temporal host to reproduce.

If they are able to do both (i.e., free-living or utilizing a host organism during certain stages) then they are intermittent, non-obligate symbionts. If they require development and growth within the host to complete their life cycle, then they are intermittent, obligate symbionts. If the latter, then it will have to be determined whether or not they are commensals or parasites during this obligate period of development within the host. This could probably be determined by molecular analysis of the gut contents of specimens recovered from the holothurian host to determine if the host holothurian DNA is present. Whether such a scenario can apply to the life cycle of T. floridanus remains to be determined and will be dependent on finding more juvenile, neuter, or reproductive adult stages on or within Biremis blandi and possible molecular comparison of gut contents with the polychaete host. Overall, the fact that only one tanaidacean species was observed in the oral cavity of $B$. blandi and it shows clear similarities to another putative symbiont species seems beyond mere coincidence.

This possible life history strategy is similar to that known in some isopod groups. Obligate intermittent parasites such as gnathid isopods develop and feed on teleost or elasmobranch hosts. At sexual maturity, they detach from their host to become free living, non-feeding components of the benthos during the mating and reproductive processes. Other isopods such as cirolanids, aegids, and their allies also exist as intermittent, obligate parasites, apparently requiring host tissue, blood, or haemolymph meal before resuming a benthic existence while they reproduce. The cymothoid isopods, which are more highly adapted to parasitism, are intermittent parasites as natatory mancas, juveniles, and protandric males, but as they moult into females lose their swimming ability, and become morphologically adapted to become obligate parasites on their fish hosts.

There also remains the possibility that the specimens recorded here are prey of $B$. blandi and that fell within the size range of the small organisms being extracted from the sediments by the terebellid tentacles. Richards (1993) concluded that B. blandi is primarily a deposit feeder consuming particles from the sediment, but some evidence of suspension feeding was also provided. Although clinging to the inner oral wall as they were found, tanaidaceans would eventually be ingested; however, the fact that only a group of immature specimens of a single species of tanaidacean was present in the oral cavity suggest that they were not there by chance or by this type of unselective feeding. Another possibility is that a nest of tanaidaceans was stuck in the oral cavity during or after collection; however, all specimens of T. floridanus were protected inside the tentacular membrane, so this would weaken the idea of an artifact related to sampling. 


\section{Acknowledgements}

We wish to thank Nancy Voss, University of Miami for making the specimens available to us for study. The specimen of Biremis blandi was granted from the collection of the University of Miami's Rosenstiel School of Marine Sciences in Miami, Florida (UMML G142). We also wish to express our appreciation to Graham Bird for his helpful and constructive comments on an early draft of the manuscript. We have tried to address most of his concerns and suggestions; however, the authors take full responsibility for any omissions or opinions that were not. Marcelo Silva-Briano and Araceli Adabache (Universidad de Aguascalientes) prepared two specimens of this tanaidacean for SEM analysis and guided our SEM observations. Rosa Ma. Hernández (El Colegio de la Frontera Sur at Chetumal), deposited specimens of the new genus in the collection of Zooplankton and provided the catalogue numbers. The comments from anonymous reviewers greatly contributed to improve previous versions of this work.

\section{References}

Anderson G. 2010. Tanaidacea Classification. Available at http:// peracarida.usm.edu/TanaidaceaTaxa.pdf. [visited July 2010]

Bamber RN, Bird G. 1997. Peracarid crustaceans from Cape d'Aguilar and Hong Kong, III. Tanaidacea: Tanaidomorpha. Pp. 103-142 in: Morton B, ed., The Marine Flora and Fauna of Hong Kong and Southern China IV. Hong Kong: Hong Kong University Press.

Błażewicz-Paszkowycz M. 2005. Singularia cuncta n. gen., n. sp. (Tanaidacea: Tanaidomorpha) from Antarctic abyssal waters. Journal of Crustacean Biology 25: 75-80.

Błażewicz-Paszkowycz M, Bamber RN. 2009. A new genus of a new Austral family of paratanaoid tanaidacean (Crustacea: Peracarida: Tanaidacea), with two new species. Memoirs of Museum Victoria 66: 5-15.

Błażewicz-Paszkowycz M, Poore GCB. 2008. Observations on phylogenetic relationships in Paratanaoidea (Tanaidacea: Tanaidomorpha). Advances in Crustacean Phylogenetics, International Symposium, Rostock (Germany): 68-69.

Knight J, Larsen K, Heard RW. 2003. A new genus and species, Tumidochelia randyi, from the Gulf of Mexico (Crustacea: Peracarida: Tanaidacea). Proceedings of the Biological Society of Washington 116: 497-502.

Kudinova-Pasternak RK. 1987. Distribution of the abyssal Expina typica and potential parasitism of tanaid crustaceans. Zoologicheskii Zhurnal 66: 1094-1096.

Kussakin OG, Tzareva LA. 1974. A new genus of Tanaidacea (Crustacea) from the Antarctic. Zoologicheskii Zhurnal 53: 125-128.
Lang K. 1949. Contribution to the systematics and synonymics of the Tanaidacea. Arkiv für Zoologie 42: 1-14.

Lang K. 1968. Deep-sea Tanaidacea. Galathea Report 9: 23 209.

Larsen K. 1999. Deep-sea tanaidaceans (Crustacea: Peracarida) from the Albatross cruises 1885-86, with keys to the suborder Neotanaidomorpha. Journal of Natural History 33: 1107-1132.

Larsen K. 2003. Proposed new standardized anatomical terminology for the Tanaidacea (Peracarida). Journal of Crustacean Biology 23: 664-661.

Larsen K. 2005. Deep-sea Tanaidacea (Peracarida) from the Gulf of Mexico. Crustaceana Monographs 5: 1-381.

Larsen K, Wilson GDF. 1998. Tanaidomorphan systematics - is it obsolete? Journal of Crustacean Biology 18: 346-362.

Larsen K, Wilson GDF. 2002. Tanaidacean phylogeny. The first step: the Superfamily Paratanaidoidea. Journal of Zoological Systematics and Evolutionary Research 40: 205-222.

Londoño-Mesa M. 2009. Terebellidae (Polychaeta: Terebellida) from the Grand Caribbean region. Zootaxa 2320: 1-93.

Morales-Vela B, Suárez-Morales E, Padilla J, Heard RW. 2008. The tanaid Hexapleomera robusta (Crustacea: Peracarida) from the Caribbean manatee, with comments on other crustacean epibionts. Journal of the Marine Biological Association of the United Kingdom 88: 591-596.

Polloni PT, Rowe GT, Teal JM. 1973. Biremis blandi (Polychaeta: Terebellidae), new genus, new species, caught by D.S.R.V. "Alvin" in the Tongue of the Ocean, New Providence, Bahamas. Marine Biology 20: 170-175.

Richards PL. 1993. Feeding behavior and morphology of the deep-sea terebellid polychaete Biremis blandi. MSc Thesis, Florida Institute of Technology

Sieg J. 1980. Taxonomische Monographie der Tanaidae Dana 1849 (Crustacea: Tanaidacea). Abhandlungen der Senckenbergischen Naturforscheden Gesellschaft 537: 1-267.

Sieg J. 1984. Tanaidacea of the United States Navy's 1947-1948 Antarctic Expedition. Journal of Crustacean Biology 4: 298-306.

Thistle D, Yingst JY, Fauchald K. 1985. A deep-sea benthic community exposed to strong near-bottom currents on the Scotland Rise (western Atlantic). Marine Geology 66: 91112.

Thurston MH, Billett DSM, Hassack E. 1987. An association between Expina typica Lang (Tanaidacea) and deep-sea holothurians. Journal of the Marine Biological Association of the United Kingdom 67: 11-15.

Received: 14 October 2010

Revised and accepted: 28 February 2011

Published online: 7 June 2011

Editor: R.W.M van Soest 


\section{Appendix}

\section{Description of the genus}

Suborder Tanaidomorpha Sieg, 1980

Superfamily Paratanaoidea Lang, 1949

Family Mirandotanaidae Błażewicz-Paszkowycz and Bamber, 2009

Genus Terebellatanais gen. nov.

Diagnosis. Body robust, cylindrical, enlarged posterior pereonites and pleon comprising more than half of body length. Carapace short. Eye-lobes prominent, eyes absent. Pleon of five free somites plus pleotelson, swollen. Pleotelson without dorsal plate. Antennule and antenna each with 4 articles. Labrum and labium simple, left mandible with blunt teeth on pars incisiva, lacinia mobilis represented by partially fused spike. Right mandible blunt, with reduced pars molaris, weakly denticulate. Maxillule with slender endite armed with five distal and one subdistal spines, palp articles fused. Epignath stick-like. Maxillipedal basis fused, endites lacking distal setae, palp with 4 articles, second one longer than wide, without branched setae. Chelipeds attached via triangular sclerite, fixed finger straight, with tooth-like inner process; dactylus curved. Pereopods slender, coxae and basis fused, dactylus and unguis not fused into hook. Basis of pereopods 1-6 longer than three succeeding articles combined. Meri of pereopods 1-3 bear a seta Pleopods absent in mancas, present in neuter. Uropods short, stout; endopod with 2 articles; exopod uniarticulate, as long as first endopodal article.

Type species. Terebellatanais floridanus sp. nov., by monotypy.

Distribution. This tanaidacean is known only from the type locality, the Florida Straits off Cay Sal Bank from a depth of $545 \mathrm{~m}$.

Taxonomic remarks. These tanaidacean specimens were first identified as belonging to the Colletteidae sensu Larsen and Wilson (2002) as modified by Larsen (2005). Currently, 16 genera are contained in this diverse family (Larsen and Wilson, 2002; Knight et al., 2003; Larsen, 2005; Błażewicz-Paszkowycz, 2005; Błażewicz-Paszkowycz and Bamber, 2009). However, a closer analysis of our specimens allowed us to determine that the new genus diverges from the general colletteid pattern by its having of: 1) enlarged posterior pereonites and pleon combined representing half or more of the total body length; 2) antenna with 4 articles, 3) reduced mouthparts, 4) maxillipedal bases fused and endites fused, 5) coxae of pereopods 4-6 absent; 6) reduced uropodal exopod; 7) setation on the uropodal peduncle with 2 exopodal and 4 endopodal terminal setae. Błażewicz-Paszkowycz and Poore (2008) recognized a strong polyphyly among the Colletteidae; later on, Błażewicz-Paszkowycz and Bamber (2009) proposed the new family Mirandotanaidae to include forms with a combination of characters that largely agree with those found in our specimens; inflated posterior pereonites and pleon on mature adults, pereon and pleon representing more than half of total body length, prominent eye-lobes and absent eyes, 4-segmented antennules, naked labrum and labium, reduced pars molaris, a cheliped attached by triangular sclerite, maxillule palp fused. Maxillipedal basis fused medially, and dactylus and unguis of pereopods 4-6 not fused. The genus diverges from the mirandotanaid pattern by its having of 4 antennal segments (instead of 6), fused basis-coxa on pereopods 1-3 (separated in this family), simple unguis (vs. bifurcate), pleopods present (vs. absent). Also, an inflated pleon has been observed only at a manca stage (vs. adults in the family), meri of pereopods 1-3 bear a seta (instead of naked). There are currently two genera contained in this family: Mirandotanais Kussakin and Tzareva, 1974 and Pooreotanais BłażewiczPaszkowycz and Bamber, 2009. Because of the poorly defined colletteid pattern (Błażewicz-Paszkowycz and Bamber, 2009), at this time our specimens seem to fit best in the current definition of the Mirandotanaidae and are tentatively assigned to this taxon.

The new genus differs from the two genera of the Mirandotanaidae (Błażewicz-Paszkowycz and Bamber, 2009), Mirandotanais and Pooreotanais. It diverges from the former in the absence of lacinia mobilis on the right mandible, absence of armature on the maxillipedal basis endite, two inner setae on article 3 of maxillipedal palp (instead of none or 1 seta), the armature of the maxillules ( 9 distal spines vs. 4 distal and 1 subdistal in the new genus), the number of antennal articles, and details of the setation pattern of the pereopods (see Kussakin and Tzareva, 1974; Sieg, 1984). It differs from Pooreotanais by a weaker mandibular denticulation, the armature of the maxillule endite (4 distal plus 1 subdistal instead of 5-9 distal spines), the maxillipedal segment 3 is longer than wide in the new genus (instead of wider than long or equally long as wide), the ischium of pereopods 1-3 bears one seta (instead of none), and the carpus of pereopods 1-3 has three setae (instead of one). 
The new genus Terebellatanais has affinities with the monotypic genus Expina, including the cephalothorax shape, absence of eyes, absence of pleopods in the manca but present at more advanced stages, chelipeds attached via sclerites, maxilliped with naked endite and similar shape, pereopods without coxae, pereopods 1-3 without strong spiniform elements, uropods biramous with two-segmented endopod and one-segmented exopod, the latter as long as first endopodal article (see Lang, 1968). Larsen (2005) considered $E x$ pina as belonging to an indeterminate family but recognized its affinities with the Colletteidae. The main differences between these two genera include the number of antennal articles, 6 in Expina vs. 4 in the new genus. In Expina the mandibles have a relatively well developed pars molaris vs. a reduced condition in the new genus; the maxillules have a broad endite and lack distal spines vs. a slender endite and presence of distal and subdistal spines in the new genus. The unguis of pereopods 4-6 have an accessory spine in Expina, this process is absent in the new genus (see Lang, 1968). An additional affinity between Expina and Terebellatanais refers to their presumed biology; Expina is a symbiont of deep-sea holothurians (Thurston et al., 1987), although it has been recorded as a free-living form elsewhere (Lang, 1968); Terebellatanais appears to be associated with a deep-sea polychaete but no adults have been recovered yet.

Etymology. The genus name is a combination of the family name of the polychaete host and the noun tanais, making reference to the presumed symbiotic association of the tanaidacean and this terebellid polychaete.

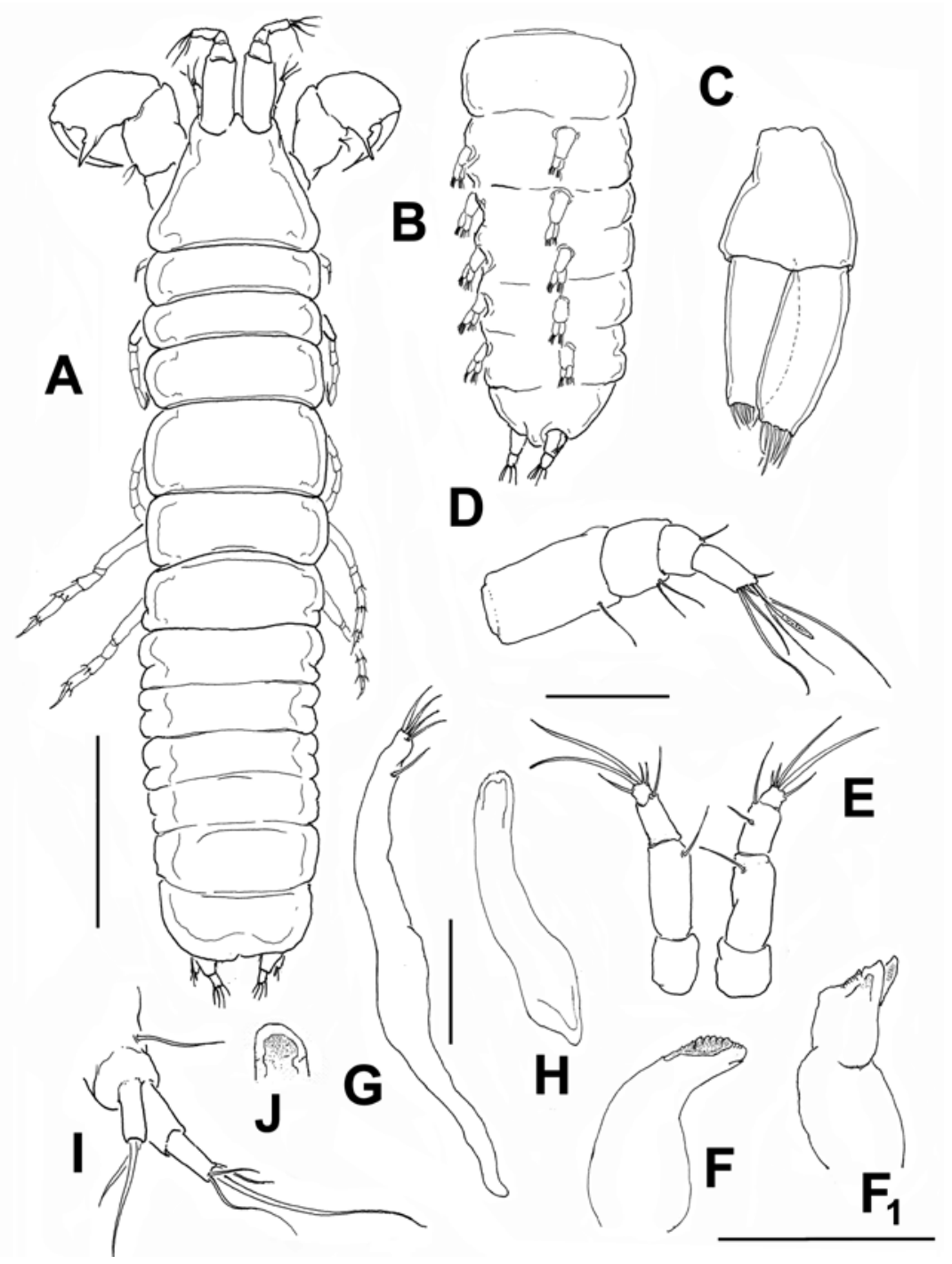

Fig. 2. Terebellatanais floridanus gen. nov., sp. nov. from B. blandi. Holotype neuter. A. dorsal view; B. ventral view of pleon; C. pleopod; D. antennule; E. antennae; F. left mandible; $F_{1}$ right mandible; G. maxillule; H. epignath; I. uropod, J. labrum. Scale bars: A,B $=0.1$ $\mathrm{mm} ; \mathrm{C}-\mathrm{J}=10 \mu \mathrm{m}$. 


\section{Terebellatanais floridanus sp. nov. (Figs 2-7)}

Material examined. Holotype neuter (non-reproductive adult) individual, from oral cavity of Biremis blandi UMML22-1013, R/V “Gerda”, Sta. 142, Straits of Florida, $24^{\circ} 15^{\prime} \mathrm{N}, 80^{\circ} 05^{\prime} \mathrm{W}, 545 \mathrm{~m}, 22 . v i .1963$. Specimen partially undissected, appendages mounted on slides (USNM-1154251). Paratypes: three mancas from same host, site, and date, undissected, ethanol-preserved, vial (ECO-CHZ-07437), manca from same host, site, and date, dissected, slide (ECO-CHZ-07438). Three mancas, same collection data, one undissected, ethanol-preserved, two dissected mounted on slides, deposited at the University of Miami (UMML-32.9731). Manca, same collection data, deposited at the Gulf Coast Research Laboratory Museum (GCRL-2988).
Type locality. Key Sal Bank, off New Providence, Bahamas, Straits of Florida, depth $545 \mathrm{~m}$.

Diagnosis of species. That of the genus.

Description. Body robust (Fig. 2A, B) cylindrical, 4.5 times as long as wide. Carapace short, subtriangular, 0.8 times longer than wide, longer than combined lengths of pereonites 1 and 2. Pereon with first pereonite 3 times wider than long. Pereonites 2-6 wider than long. Pleon robust, slightly swollen, representing slightly more than 0.35 times total body length. Pleon with five free pleonites, marked by relatively shallow sutures ventrally. All pleonites subequal, as wide as but mostly shorter than pereonites. Pleotelson without dorsal plate, longer than or as long as last pleonite. Mancas with swollen, weakly segmented pleon and different proportional size (Fig. 4C-F).

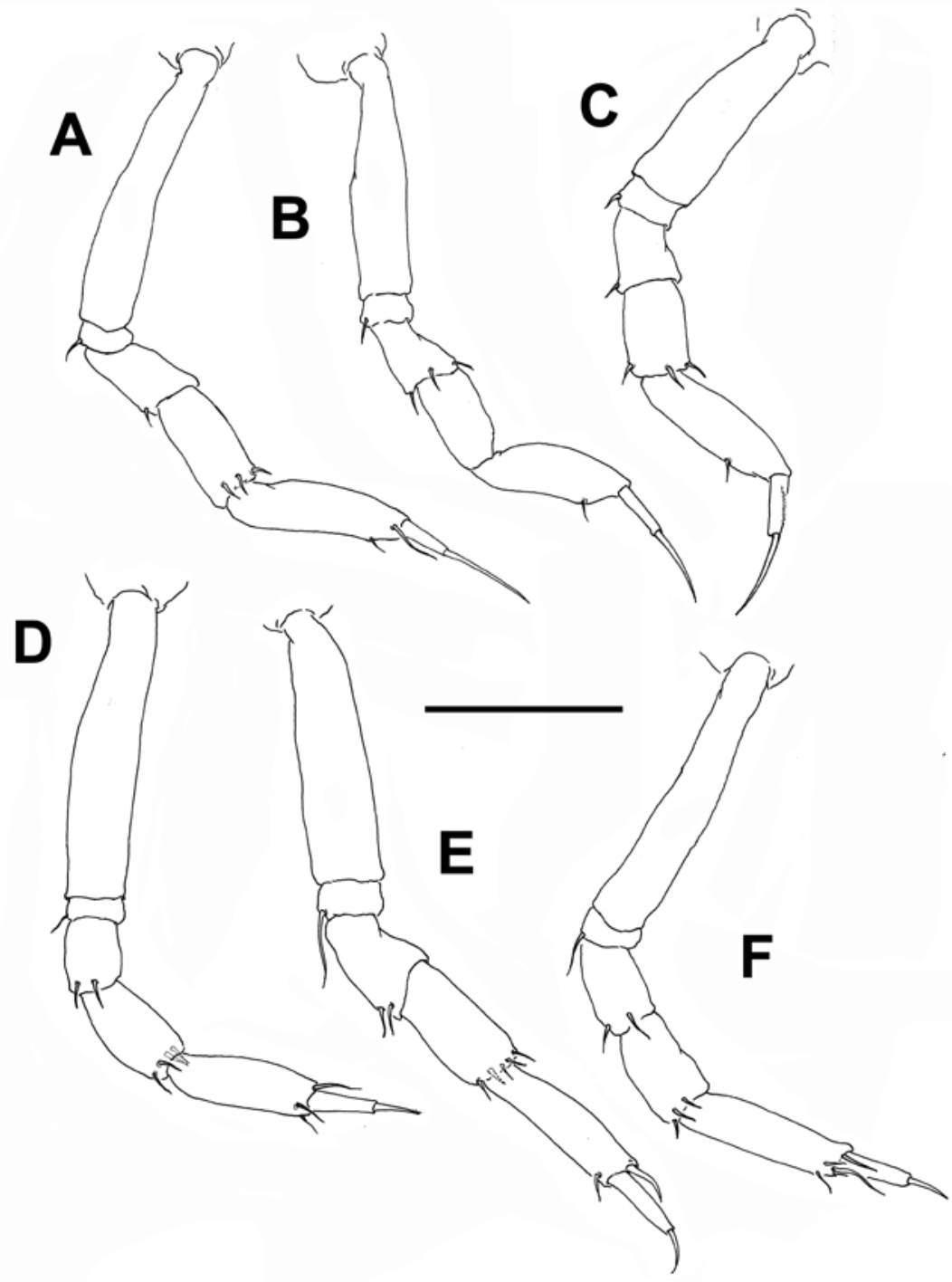

Fig. 3. Terebellatanais floridanus gen. nov., sp. nov. from B. blandi. Holotype neuter. A. pereopod 1; B. pereopod 2; C. pereopod 3; D. pereopod 4; E. pereopod 5; F. pereopod 6. Scale bars $=50 \mu \mathrm{m}$. 
Antennule (Fig. 2A, D) with four articles, shorter than carapace. First article robust, shorter than rest of antennule, with one simple seta subdistally. Second antennular article as long as terminal article, with two setae distally. Third article shorter than preceding article, with one short seta distally. Terminal article less than 0.5 times as long as first article, with 5 simple setae and one aesthetasc distally. Surface of article ornamented with transverse rows of spinules (Fig. 7A).

Antenna (Fig. 2E) with four articles; shorter than antennule. First article subquadrate, naked. Second article twice as long as first, with single seta inserted subdistally. Third antennal article 0.5 times as long as second article, with one short seta medially and one distal seta. Article 4 shortest, about 1/3 the length of first article, armed with three long and two short setae inserted distally.

Mouthparts. Labrum hood-shaped, naked. Labium simple, with two naked lobes. Left mandible (Fig. 2F) with distal surface bearing 5 low, blunt teeth distally on pars incisiva; lacinia mobilis reduced to a partially fused spike. Right mandible (Fig. $2 \mathrm{~F}_{1}$ ) blunt, with two large teeth with rugose surface. Maxillule reduced, endite slender, armed with 4 distal and 1 subdistal spines; palp fused, distally naked (Fig. 2G). Epignath represented by stick-like structure, distally rounded (Fig. $2 \mathrm{H}$ ). As usual in tanaidomorphans, maxilla reduced, ovoid, naked (not shown).

Maxilliped (Fig. 4A) basis narrowly triangular, inner margin naked, with one small seta at insertion of palp, endites subtriangular, rounded distally, naked.
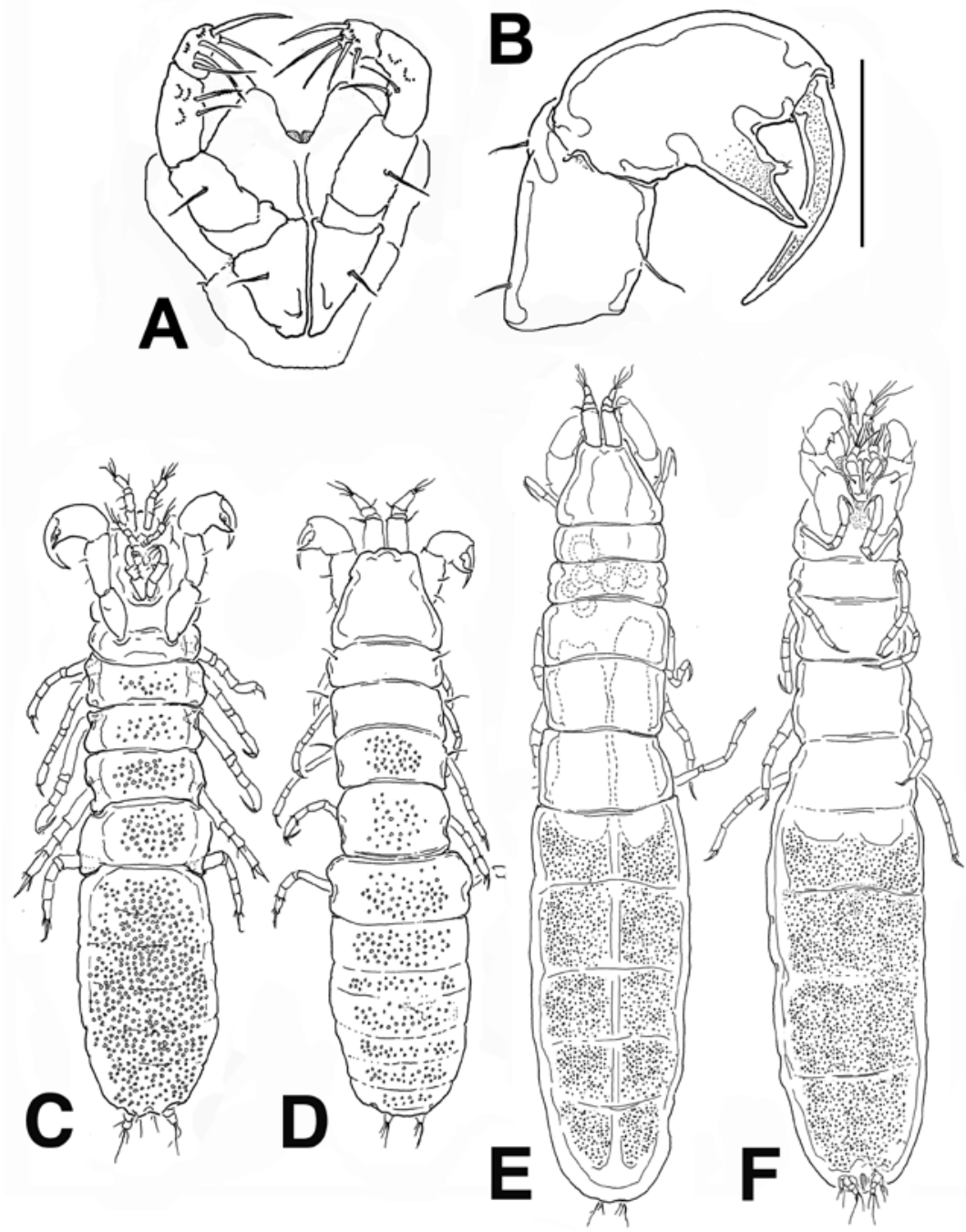

Fig. 4. Terebellatanais floridanus gen. nov., sp. nov. from B. blandi. Neuter. A. maxilliped, ventral view, B. distal articles of cheliped, rows of cuticular spinules not illustrated; C. manca, ventral view; D. manca, dorsal view; E. manca with swollen pleon, dorsal view; F. manca with swollen pleon, ventral. Scale bars $\mathrm{A}-\mathrm{B}=0.3 \mathrm{~mm} ; \mathrm{C}-\mathrm{F}=100 \mu \mathrm{m}$. 
First segment of palp cylindrical. Second segment elongate, longer than wide, with outer seta on middle outer surface. Third article relatively long, slightly curved, with two inner setae; fourth article with five setae, innermost seta shortest, articles 3 and 4 with curved rows of spinules. Mancas with similar structure (Figs 5A, 6E).

Cheliped (Fig. 4B) robust, attached via sclerite, basis widening distally, about as long as carpus, twice as long as merus. Merus with one seta ventrally (Fig. 5B). Carpus shorter than propodus including fixed finger, with two setae, one inserted ventro-medially, the other on dorso-distal position. Propodus naked at dactylus insertion, propodus with several curved rows of spinules on inner surface (Fig. 6D). Fixed finger strong, straight, with medial tooth-like process bearing cluster of short setae. Dactylus long, curved naked, shorter than propodus. Cheliped with same structure in mancas (Figs 5B, 6C, D).

Pereopod 1 (Fig. 3A) coxa fused to pereonite. Basis 1.6 times longer than three succeeding articles combined, naked. Ischium short, with short seta. Merus slightly shorter than carpus, widening distally, with distal short seta. Carpus 0.5 times as long as propodus, with three short setae distally. Propodus 0.7 times as long as basis, with one subdistal seta and one long distal seta. Dactylus/unguis not fused into hook, combined 0.7 times as long as propodus. Unguis straight, twice as long as dactylus. In mancas, basis with proximal seta, ischium and merus naked, carpus with two setae, propodus with single subdistal seta, unguis as long as dactylus (Fig. 5C).
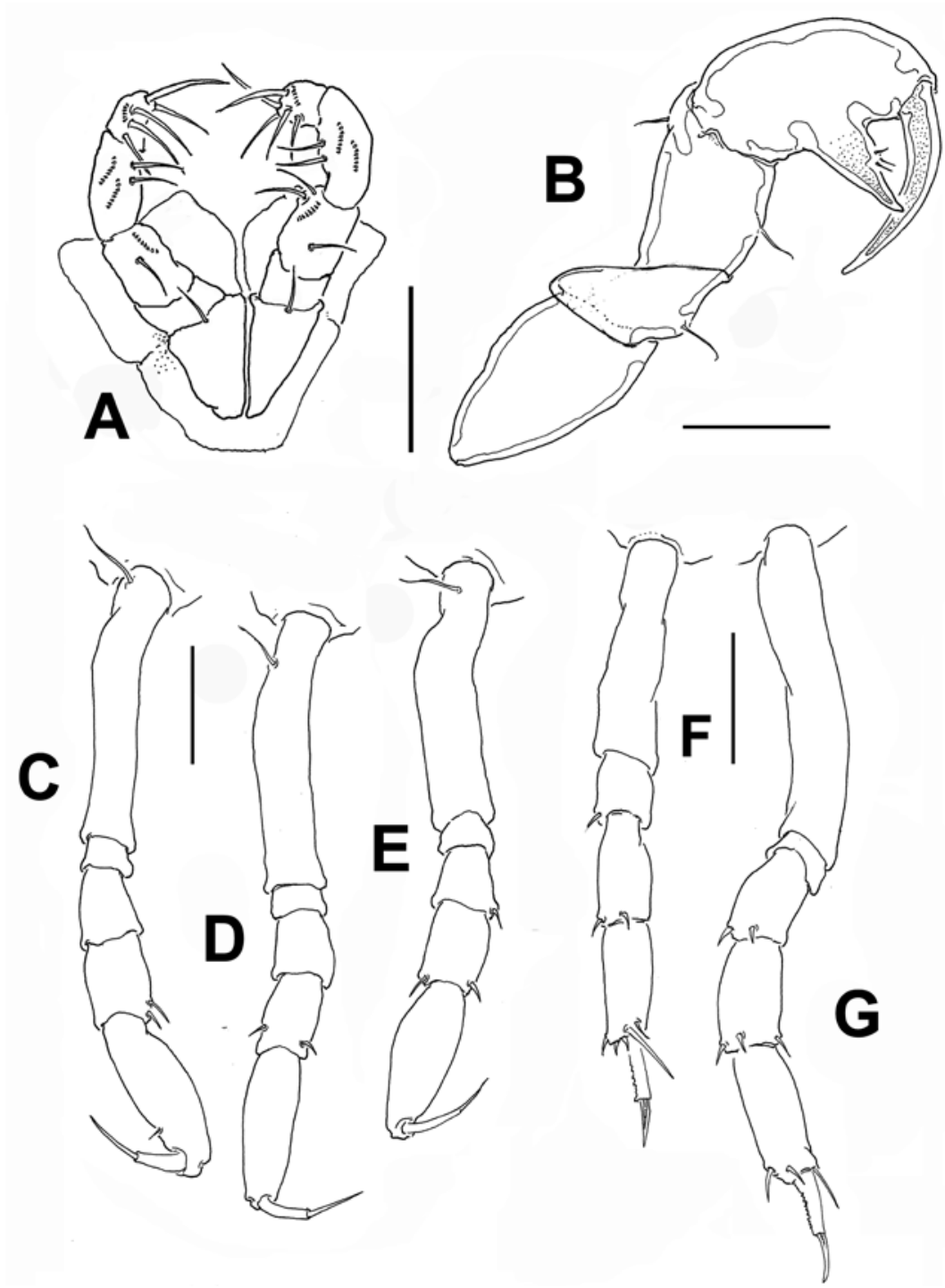

Fig. 5. Terebellatanais floridanus gen. nov., sp. nov. from B. blandi. Manca. A. maxilliped; B. cheliped; C. pereopod 1; D. pereopod 2; E. pereopod 3; F. pereopod 4; G. pereopod 5. Scales $=35 \mu \mathrm{m}$. 
Pereopod 2 (Fig. 3B) as pereopod 1 except: merus with three setae, carpus naked, propodus without distal seta, unguis and dactylus equally long. In mancas (Fig. 5D), seta present on basis, merus and carpus naked.

Pereopod 3 (Fig. 3C) as pereopod 2 except: basis relatively shorter, but still 1.3 times longer than three succeeding articles, merus with short spiniform seta, as in pereopod 1. Three short setae on carpus. Dacty- lus longer than unguis. In mancas (Fig. 5E) seta on basis present, carpus with two setae, propodus naked.

Pereopod 4 (Fig. 3D) as pereopod 3 except: longer basis, merus with two setae, carpus with four setae, propodus with three distal setae. In mancas (Fig. 5F) seta on basis absent, ischium reduced or absent. Carpus with two short setae distally. Propodus with four short and one long setae distally. Unguis short, dactylus serrate.
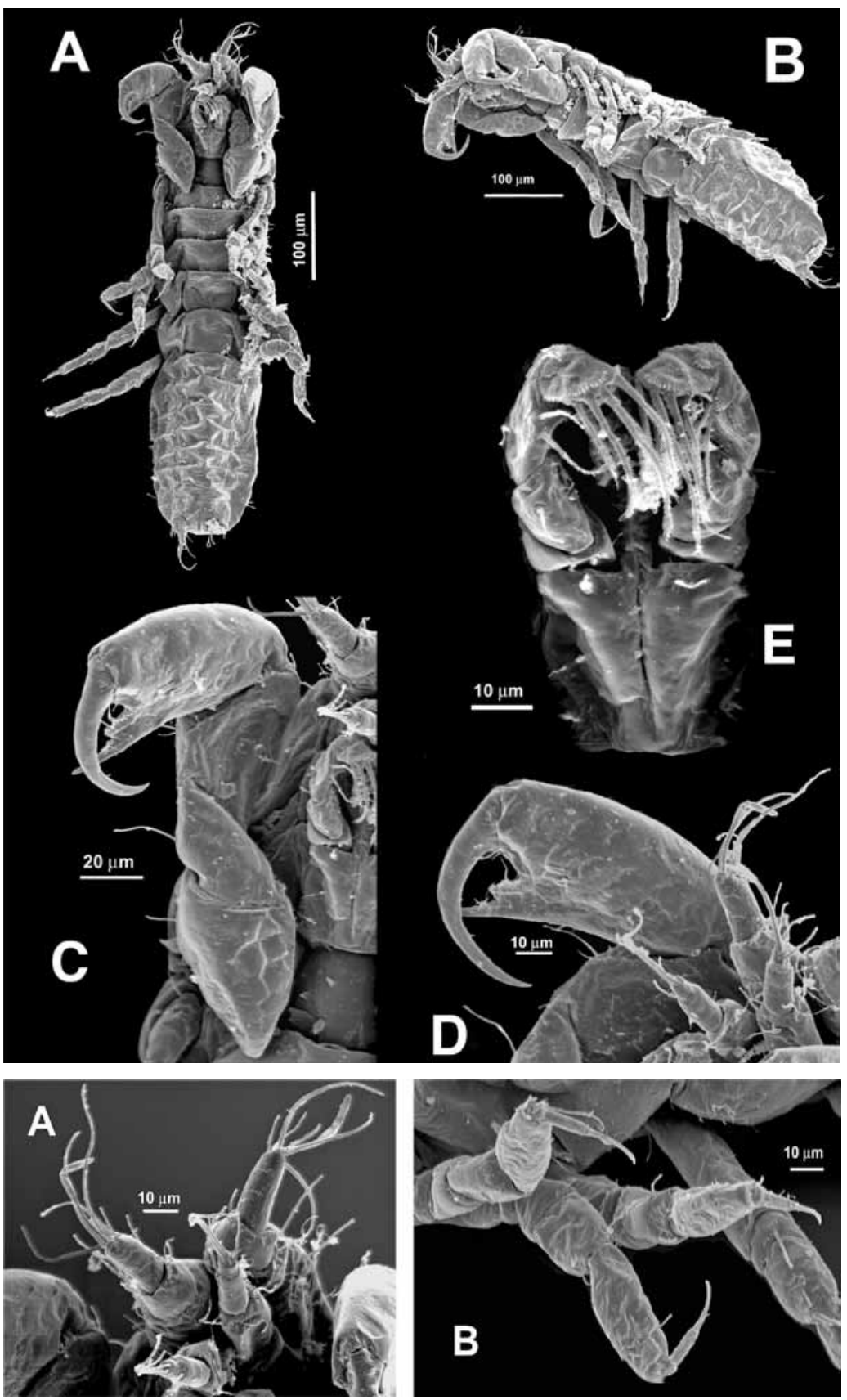

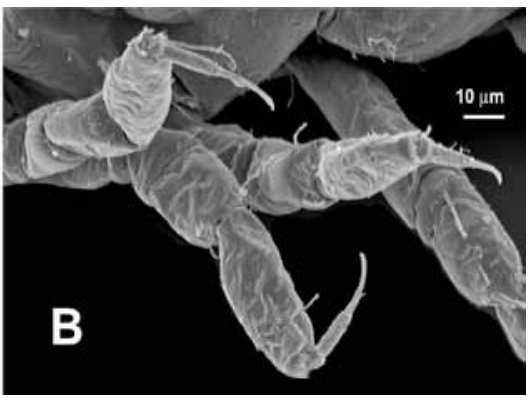

Fig. 6. Terebellatanais floridanus gen. nov., sp. nov. from B. blandi. Manca. A. habitus, ventral view; B. same, semi-lateral view; C. cheliped, ventral view; D. detail of surface ornamentation of chela; E. maxilliped, ventral view.

Fig. 7. Terebellatanais floridanus gen. nov., sp. nov. from $B$. blandi. Manca. A. antennules and antennae, ventral view; B. pereopods 1-3. 
Pereopod 5 (Fig. 3E) as pereopod 4 except: longer seta on ischium (at least 3 times as long as in pereopods 1-4), 4-5 short setae on carpus, propodus with two distal setae. In mancas (Fig. 5G) seta on basis absent, ischium naked, carpus with three short distal setae, propodus with two short and one long spiniform setae; dactylus longer than unguis, with inner margin serrate.

Pereopod 6 (Fig. 3F) as pereopod 5 except: shorter seta on ischium, three setae on carpus, four setae on propodus.
Pleopods (Fig. 2C) biramous, subrectangular, each ramus with terminal row of short setae. Absent in mancas.

Uropods (Fig. 2H) with basis armed with single seta; endopod with two segments, first segment as long as exopod, with one distal seta. Second article with one long seta and three shorter setae inserted distally. Single exopodal article with two subequal simple setae distally.

Etymology. The species is named in reference to the general geographical area in which it was recorded. The name is in male gender to agree with the generic name. 


